\title{
KONTRIBUSI KOMPETENSI DAN KEPUASAN KERJA SERTA IMPLIKASINYA TERHADAP KINERJA PERAWAT RUMAH SAKIT UMUM DAERAH DI SAMARINDA DAN BALIKPAPAN
}

\author{
Edi Sukamto, Rasmun \\ Politeknik Kesehatan Kementerian Kesehatan Kalimantan Timur \\ edidiharjo2@gmail.com
}

\begin{abstract}
Regional General Hospital requires nurses who are able to do more than just formal tasks and are willing to give good performance. Nurses want better performance to carry out their functions. Achieving optimal performance can be done if the nurse has competence, besides that nurse satisfaction is also a determining factor in Nurse performance. The purpose of this study was to determine the effect of competence on job satisfaction and performance. The population in this study was the Implementing Nurse. The sampling technique is Purpossive Sampling. The samples in this study were all nurses working in the inpatient ward of the IA Moeis Regional General Hospital in Samarinda, the Believers Regional General Hospital in Balikpapan, totaling 128 nurses in the inpatient room in the IA Moeis Regional General Hospital in Samarinda, the Regional General Hospital in the Believers in Balikpapan. This research is a quantitative study using a questionnaire as a means of collecting data. This research was analyzed using the WarpPLS program. The results of this study indicate that competence has a significant positive effect on satisfaction. Competence gives an insignificant negative effect on performance. Satisfaction gives a significant positive effect on performance. Recommendations in this study are expected to continue to make regular improvements with nurses regarding optimizing the achievement of competencies both individually and collectively, expected to provide a fair and objective assessment of the quality of work so as to encourage satisfaction with improving nurse performance.
\end{abstract}

Keywords: Competence, Satisfaction, Nurse Performance

\begin{abstract}
Abstrak: Rumah Sakit Umum Daerah membutuhkan perawat yang mampu melakukan pekerjaan lebih dari sekadar tugas formalnya dan mau memberikan kinerja yang baik. Perawat menginginkan kinerja lebih baik untuk melaksanakan fungsinya. Pencapaian kinerja yang optimal dapat dilakukan apabila perawat mempunyai kompetensi, selain itu kepuasan perawat juga menjadi faktor penentu kinerja Perawat. Tujuan dalam penelitian ini adalah untuk mengetahui pengaruh kompetensi terhadap kepuasan kerja dan kinerja. Populasi dalam penelitian ini adalah Perawat Pelaksana. Teknik pengambilan sampel adalah Purpossive Sampling. Sampel pada penelitian ini adalah seluruh perawat yang bekerja di ruang rawat inap Rumah Sakit Umum Daerah IA Moeis Samarinda, Rumah Sakit Umum Daerah Beriman Balikpapan, yang berjumlah 128 perawat di ruang rawat inap Rumah Sakit Umum Daerah IA Moeis Samarinda, Rumah Sakit Umum Daerah Beriman Balikpapan. Penelitian ini adalah penelitian kuantitatif dengan menggunakan kuesioner sebagai sarana pengumpulan data. Penelitian ini dianalisis dengan menggunakan program WarpPLS. Hasil penelitian ini menunjukkan kompetensi memberikan pengaruh positif signifikan terhadap kepuasan. Kompetensi memberikan pengaruh negatif tidak signifikan terhadap kinerja. Kepuasan memberikan pengaruh positif signifikan terhadap kinerja. Rekomendasi dalam penelitian ini Rumah Sakit diharapkan terus melakukan perbaikan secara berkala dengan Perawat mengenai optimalisasi pencapaian kompetensi baik secara individual maupun kolektif, diharapkan agar memberikan penilaian yang adil dan objektif terhadap kualitas kerja sehingga mendorong kepuasan terhadap peningkatan kinerja perawat.
\end{abstract}

Kata Kunci: Kompetensi, Kepuasan, Kinerja Perawat 
SDM rumah sakit yang paling banyak berinteraksi secara langsung dengan pelanggan atau pasien adalah perawat. Selain itu, perawat juga merupakan SDM dengan jumlah terbesar yang bekerja di rumah sakit (Gillies: 1994). Loveridge \& Cumming (1996), Perawat memberikan pelayanan secara terus-menerus selama 24 jam dan 7 hari dalam seminggu. Di sisi yang lain, perawat dituntut harus memiliki kompetensi kompleks dan profesional serta bekerja pada iklim dan manajemen yang baik (Swansburg \& Swansburg, 1999), sehingga kualitas pelayanan yang dilaksanakan oleh perawat dapat dinilai sebagai salah satu indikator baik atau buruknya kualitas dan citra pelayanan di rumah sakit (Depkes RI, 1994). Mengingat perawat adalah SDM terpenting dalam menjalankan pelayanan suatu RS, maka perawat dituntut memiliki kemampuan intelektual, interpersonal, teknikal dan komitmen moral atau etika yang memadai, dalam melaksanakan pekerjaannya.

Pemberian kualitas pelayanan yang baik, tentunya akan melibatkan orang-orang yang profesional dan ahli di bidangnya. Dalam bidang kesehatan misalnya, tenaga kesehatan yang akan dilibatkan di antaranya adalah perawat. Perawat menjadi salah satu bagian yang penting dalam pemberian pelayanan kesehatan. Perawat adalah tenaga kesehatan yang berperan memberi asuhan keperawatan pada pasien secara langsung, mengikuti timbang terima, melaksanakan tugas yang didelegasikan dan mendokumentasikan asuhan keperawatan (Suarli \& Bahtiar, 2009:89). Tugas perawat tersebut menunjukkan bahwa perawat harus memiliki kemampuan dalam memberikan pelayanan. Kemampuan perawat dalam memberikan pelayanan dan pemenuhan kebutuhan pasien dapat dilihat dari kompetensi yang dimiliki oleh perawat. Hal tersebut menunjukkan bahwa kompetensi perawat dapat menentukan kualitas dari pelayanan kesehatan.

Rumah Sakit Umum Daerah (RSUD) membutuhkan sosok perawat yang mau dan mampu melakukan pekerjaan lebih dari sekadar tugas formalnya dan mau memberikan kinerja yang melebihi harapan. Perawat dengan kemampuan seperti ini cukup langka, padahal perawat menginginkan kinerja lebih baik untuk melaksanakan tugas pokok dan fungsinya di daerah. Dalam dunia kerja yang dinamis seperti saat ini, yang mana tugas makin sering dikerjakan dalam tim, fleksibilitas sangatlah penting. Untuk itu organisasi menginginkan karyawan yang bersedia melakukan tugas yang tidak tercantum dalam deskripsi pekerjaannya.

Pemilihan RSUD di Samarinda dan Balikpapan sebagai tempat penelitian adalah perawat yang mempunyai pengalaman yang tinggi sehingga mampu mencerminkan kondisi perawat secara umum, rumah sakit tersebut merupakan rumah sakit yang masuk 
dalam kategori rumah sakit rujukan dengan tingkat aktivitas yang tinggi, sehingga masalah yang dapat dirumuskan pada penelitian ini adalah: 1) Apakah kompetensi berpengaruh signifikan terhadap kepuasan kerja Perawat RSUD di Samarinda dan Balikpapan? 2) Apakah kompetensi berpengaruh signifikan terhadap kinerja Perawat RSUD di Samarinda dan Balikpapan? 3) Apakah kepuasan kerja berpengaruh signifikan terhadap kinerja Perawat RSUD di Samarinda dan Balikpapan?

\section{BAHAN DAN CARA KERJA}

Operasionalisasi variabel adalah menjabarkan variabel menurut dimensi dan indikatornya sebagai berikut:

Kompetensi (X). Indikator dari variabel kompetensi sebagai berikut: Komunikasi; perawat mempunyai kemampuan untuk berkomunikasi baik dengan rekan kerja maupun atasan serta pengguna jasa, pengambilan keputusan; perawat mempunyai kemampuan untuk mengambil keputusan dalam berbagai kondisi, penyelesaian masalah; perawat mempunyai kemampuan untuk menyelesaikan masalah dengan kemampuan sendiri, peningkatan kualitas; perawat mempunyai kemampuan untuk meningkatkan kualitas kerja, fokus pada pelayanan; perawat mempunyai kemampuan untuk selalu fokus dengan pemberian pelayanan, kerjasama; perawat mempunyai kemampuan untuk selalu fokus dengan pemberian pelayanan.

Kepuasan Kerja $\left(\mathrm{Y}_{1}\right)$. Indikator dari variabel kepuasan kerja sebagai berikut: Puas terhadap pekerjaan itu sendiri; Perawat telah puas dengan pekerjaan yang dilakukan sekarang karena sesuai dengan kemampuan dan keahlian perawat, puas terhadap gaji atau upah; Perawat merasa puas dengan gaji yang diberikan, puas terhadap promosi; Perawat merasa puas dengan promosi yang diberikan karena mempunyai kesempatan untuk memperoleh peningkatan karir selama bekerja, puas terhadap hubungan dengan atasan; Perawat merasa puas dengan hubungan pekerjaan dengan atasan, puas terhadap teman sekerja; Perawat merasa puas dengan lingkungan teman sekerja maupun pegawai lain yang berbeda jenis pekerjaannya

Kinerja pegawai $\left(\mathrm{Y}_{2}\right)$. Indikator dari variabel kinerja sebagai berikut: Kualitas Kerja; Tingkat efisiensi kualitas kerja yang dicapai dari perawat baik secara individu atau secara kolektif telah sesuai dengan harapan instansi, Kuantitas Kerja; Tingkat efisiensi hasil kerja yang dicapai dari perawat baik secara individu atau secara kolektif telah sesuai dengan harapan instansi, pengetahuan perawat; Tingkat pengetahuan perawat tersebut dalam menyelesaikan pekerjaan yang telah sesuai dengan harapan instansi, Kreativitas perawat dalam 
perencanaan kerja untuk mencapai tujuan organisasi yang lebih efektif berjalan dengan efektif, Kemampuan kerjasama dan kemampuan pengembangan ide-ide program yang disampaikan perawat dalam mencapai tujuan pelaksanaan pelayanan kepada publik sesuai dengan harapan instansi.

Penelitian ini populasinya adalah seluruh perawat di rawat inap RSUD di Samarinda dan Balikpapan yang terdiri dari RSUD IA Moeis Samarinda dan RSUD Beriman Balikpapan yang keseluruhannya berjumlah 128 perawat. Sampel pada penelitian ini adalah perawat di RSUD IA Moeis Samarinda sebanyak 72 perawat dan RSUD Beriman Balikpapan sebanyak 56 perawat.

Data dalam penelitian ini dikumpulkan melalui metode angket, yaitu dengan mengajukan sejumlah daftar pernyataan kepada responden yang disesuaikan dengan tujuan penelitian. Angket pada penelitian ini dibuat berdasarkan indikator dari masingmasing variabel penelitian. Sedangkan skala pengukuran dari angket digunakan skala Likert. Metode analisa data yang digunakan dalam penelitian ini, yaitu Structural Equation Modelling (SEM) dengan menggunakan program WarpPLS. Kelebihan PLS adalah kemampuannya memetakan seluruh jalur ke banyak variabel dependen dalam satu model penelitian yang sama dan menganalisis semua jalur dalam model struktural secara simultan.

\section{HASIL}

Model Penelitian dengan Menggunakan Partial Least Square (PLS)

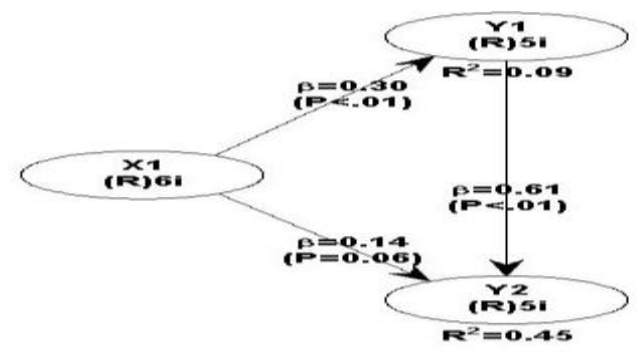

Gambar 1: Model Penelitian (Eliminasi I)

Pada model penelitian, syarat loading factor di atas 0,50 mencerminkan loading factor yang menggambarkan variabel. Indikator yang dieliminasi dalam model penelitian mula-mula adalah indikator X1.1, X1.2, Y1.2, Y2.1, Y2.2 diperoleh model penelitian yang baru dengan gambar sebagai berikut:

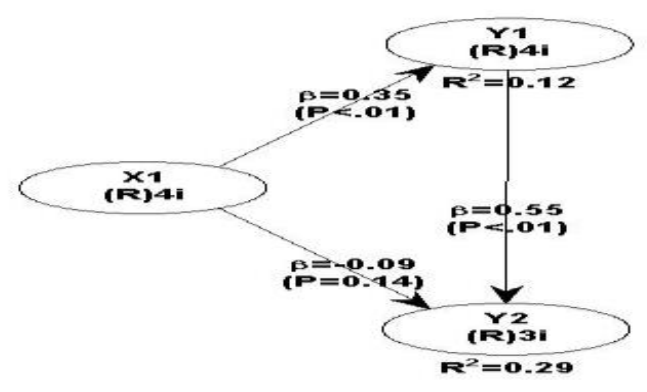

Gambar 2: Model Penelitian (Eliminasi II)

Indikator yang dieliminasi dalam model penelitian mula-mula adalah indikator X1.3 sehingga diperoleh model penelitian yang baru dengan gambar sebagai berikut:

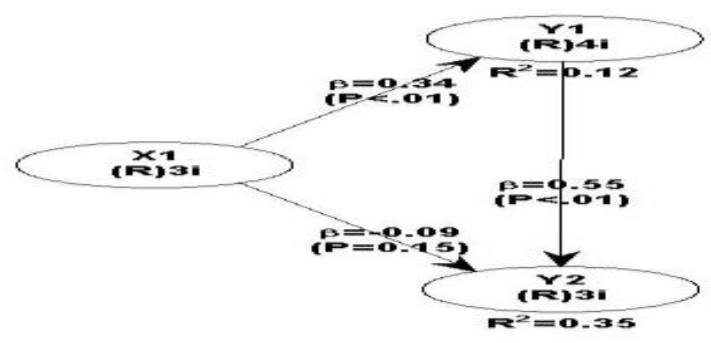

Gambar 3: Model Penelitian yang Baru 
Berdasarkan gambar semua loading factor nilainya di atas 0,50 sehingga penelitian dapat dilanjutkan untuk menganalisis model pengukuran atau outer model dan model structural atau inner model.

\section{Pengujian t-test}

Persamaan struktural menjelaskan pengaruh variabel eksogen terhadap variabel endogen, terdapat dua fungsi eksogen terhadap endogen yang dijelaskan dalam model penelitian, yang dapat dilihat pada Tabel sebagai berikut :

Tabel: Results for Inner Weights

\begin{tabular}{|c|c|c|c|}
\hline & $\begin{array}{l}\text { Original } \\
\text { Sample }\end{array}$ & $\begin{array}{c}\mathrm{P} \\
\text { Value }\end{array}$ & $\begin{array}{c}\text { Interpretasi } \\
\text { Nilai }\end{array}$ \\
\hline $\begin{array}{l}\text { Kompetensi } \\
\text { Berpengaruh } \\
\text { Terhadap } \\
\text { Kepuasan } \\
\text { Perawat }\end{array}$ & 0,344 & 0,001 & $\begin{array}{c}\text { Positif } \\
\text { Signifikan }\end{array}$ \\
\hline $\begin{array}{l}\text { Kompetensi } \\
\text { Berpengaruh } \\
\text { Terhadap } \\
\text { Kinerja Perawat }\end{array}$ & $-0,090$ & 0,149 & $\begin{array}{c}\text { Negatif } \\
\text { tidak } \\
\text { Signifikan }\end{array}$ \\
\hline $\begin{array}{l}\text { Kepuasan Kerja } \\
\text { Berpengaruh } \\
\text { Terhadap } \\
\text { Kinerja Perawat }\end{array}$ & 0,552 & 0,001 & $\begin{array}{c}\text { Positif } \\
\text { Signifikan }\end{array}$ \\
\hline Sulom & 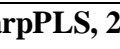 & & \\
\hline
\end{tabular}

diketahui pengaruh positif dan tingkat signifikansi masing-masing variabel, apabila P-Value $<0,05$ berarti variabel eksogen memberikan pengaruh signifikan terhadap variabel endogen dan apabila P-Value > 0,05 .

\section{PEMBAHASAN}

\section{Kompetensi berpengaruh terhadap kepuasan kerja Perawat}

Kompetensi berpengaruh positif signifikan terhadap kepuasan kerja Perawat RSUD IA Moeis Samarinda dan RSUD Beriman Balikpapan. Dengan demikian maka hipotesis pertama diterima. Hasil penelitian ini mengkonfirmasi teori Armstrong \& Baron, (1995), Armstrong, (2000), Wexley \& Yukl (2005), Colquitt et al. (2009), Kreitner \& Kinicki, (2008), Robbins \& Judge (2015), Luthans (2002), Gibson, (2008) yang menyatakan bahwa kompetensi mampu meningkatkan kepuasan kerja. Fakta yang ditemukan pada penelitian ini, menunjukkan adanya pengaruh positif kompetensi terhadap kepuasan kerja, dengan pengaruh signifikan. Secara empirik, temuan ini tidak sejalan penelitian terdahulu, yang dikemukakan oleh Haerani (2003), Yukl (2007) menyatakan bahwa kompetensi berpengaruh tidak signifikan terhadap kepuasan kerja. Berbeda dengan penelitian terdahulu lainnya yang dilakukan oleh Bogner \& Thomas (2014), Renyut et al. (2017), Jusmin et al. (2016) menyatakan bahwa kompetensi berpengaruh signifikan terhadap kepuasan kerja. Temuan ini mengindikasikan bahwa kompetensi yang dikembangkan oleh RSUD IA Moeis Samarinda dan RSUD Beriman Balikpapan terbukti secara ilmiah mampu meningkatkan kepuasan kerja Perawat.

\section{Kompetensi berpengaruh terhadap kinerja Perawat}

Kompetensi berpengaruh negatif tidak signifikan terhadap kinerja Perawat RSUD 
IA Moeis Samarinda dan RSUD Beriman Balikpapan. Dengan demikian, hipotesis kedua ditolak. Hasil penelitian ini belum mampu mengkonfirmasi teori Armstrong \& Baron, (1995), Armstrong, (2000), Baron \& Greenberg (1990) Werther \& Davis (1996), Schuler \& Jackson (1999), Bernardin \& Russel (2000), Mc.Cleland (1997) Mathis \& Jackson (2006), Gibson, (2008) yang menyatakan bahwa kompetensi mampu meningkatkan kinerja. Fakta yang ditemukan pada penelitian ini, menunjukkan adanya pengaruh positif kompetensi terhadap kinerja, dengan pengaruh tidak signifikan. Hasil penelitian ini sejalan dengan hasil penelitian terdahulu yang dilakukan oleh Ley, et al. (2007), Qamariah \& Fadli (2011), Suprapto (2009), Zaim, et al. (2013) menyatakan bahwa kompetensi berpengaruh tidak signifikan terhadap kinerja. Berbeda dengan penelitian yang dilakukan oleh Winanti (2011), Sriwidodo \& Haryanto (2010) menyatakan bahwa kompetensi berpengaruh signifikan terhadap kinerja. Winanti (2011) dalam penelitiannya menyimpulkan bahwa kompetensi berpengaruh terhadap kinerja SDM. Kinerja dan keefektifan pegawai dalam melaksanakan tugas sangat ditentukan oleh kompetensi yang disyaratkan oleh bidang pekerjaan (Sriwidodo \& Haryanto, 2010).

\section{Kepuasan kerja berpengaruh terhadap kinerja Perawat}

Kepuasan kerja berpengaruh positif signifikan terhadap kinerja Perawat RSUD IA Moeis Samarinda dan RSUD Beriman Balikpapan. Dengan demikian, hipotesis kedua belas diterima. Hasil penelitian ini mampu mengkonfirmasi teori Wexley \& Yukl (2005), Colquitt et al. (2009), Kreitner \& Kinicki, (2008), Robbins \& Judge (2015), Luthans (2002), Gibson, (2008) Robbins (2001), Baron \& Greenberg (1990) Schuler \& Jackson (1999), Bernardin \& Russel (2000), Mc.Cleland (1997) Mathis \& Jackson (2006), Gibson, (2008) yang menyebutkan bahwa kepuasan kerja mampu meningkatkan kinerja. Fakta ini mendukung penelitian terdahulu yang dilakukan oleh Palagia, (2010), Jahangir (2004), Kristensen \& Nielsen (2004) menyatakan bahwa kepuasan berpengaruh signifikan terhadap kinerja. Berbeda dengan penelitian terdahulu lainnya yang dilakukan Brouwers \& Tomic (2000), Caprara et al. (2003), Malone (2006), Greenglass \& Burke (2003) menyatakan bahwa kepuasan berpengaruh tidak signifikan terhadap kinerja.

\section{KESIMPULAN}

Kompetensi berpengaruh positif signifikan terhadap kepuasan kerja Perawat RSUD di Samarinda dan Balikpapan. Kompetensi berpengaruh negatif tidak signifikan terhadap kinerja Perawat RSUD IA Moeis Samarinda dan RSUD Beriman Balikpapan. Kepuasan kerja berpengaruh positif signifikan terhadap kinerja Perawat 
RSUD IA Moeis Samarinda dan RSUD Beriman Balikpapan.

Rumah Sakit diharapkan terus melakukan perbaikan secara berkala yang dilakukan bersama-sama dengan Perawat mengenai optimalisasi pencapaian kompetensi Perawat baik secara individual maupun kolektif agar tercapai tujuan RSUD. Untuk Perawat diharapkan mempunyai kemampuan yang lebih baik untuk melakukan kerja sama dengan rekan kerja maupun atasan serta pengguna jasa dalam hal ini pasien dan keluarganya, Perawat RSUD

\section{DAFTAR RUJUKAN}

Armstrong, Michael and Baron, A. (1995). Performance Management: The New Realities, Institute of Personnel and Development, New York.

Armstrong, Michael, (2000). Manajemen Sumber Daya Manusia, A Handbook of Human Resources Management, Terjemahan Agus Dharma. Jakarta, PT.Elex Media Komputindo

Baron, R. A., and Greenberg, J. (1990). Behavior in Organization: Understanding and Managing the Human Side of Work Third Edition ed.. Toronto: Allyn and Bacon.

Bernardin, and Russel. (2010). Human Resources Management. New York: Mc Graw Hill.

Bogner, W.C. and H. Thomas. (2014). Core Competences and Competitive Advantage: A Model and Illustrative Evidence from Pharmaceutical Industry, in Hamel, G. and W. Heene (Eds.), Competences-based Competition, New York: John Wiley and Sons.

Brouwers, Andre. Tomic, Welko. (2000). A longitudinal study of teacher burnout and perceived self-eficacy in classroom management. Teaching and Teacher Education 16 (2000) 239-253

Caprara, Gian Vittorio. Barbaranelli, Caludio. Borgogni, Laura. Steca, Patrizia. Efficacy Beliefs as Determinants of Teachers' Job Satisfaction. Journal of Educational Psychology 95 (4):821-832 - December 2003

Colquitt, J. A. (2009). Organization Behavior: Improving performance and commitment in the workplace. New York : McGraw-Hill Irwin. diharapkan untuk meningkatkan kompetensi dalam hal kemampuan mengambil keputusan dalam berbagai kondisi, sehingga mampu mendorong perasaan puas Perawat akan lingkungan teman sekerja ataupun terhadap Perawat lainnya yang mempunyai jenis pekerjaan yang berbeda, Untuk Penelitian Selanjutnya, Penelitian selanjutnya diharapkan dapat mencari ruang lingkup penelitian yang lebih luas dengan jumlah observasi penelitian dan sampel yang lebih besar supaya penelitian dapat digeneralisasikan.

Depkes RI. (1994). Standar Peralatan, Ruang dan Tenaga Rumah Sakit. Dirjen Yanmed. Jakarta.

Gibson, I. (2008). Organisasi. Terjemahan: Agus Dharma. Jakarta: Binarupa Aksara.

Gillies, Dee Ann. (1994). Nursing Management A Systems Approach. Third Edition, A Division of Harcourt Brace and Company. USA.

Greenglass, E. R., \& Burke, R. J. (2003). Teacher stress. In M. F. Dollard, A. H. Winefield, \& H. R. Winefield (Eds.), Occupational stress in the service professions (pp. 213-236). New York: Taylor \& Francis.

Haerani, S. (2003). Pengaruh Perubahan Organisasi terhadap Peluang Karir, Stres, Komitmen Organisasi, Kepuasan Kerja dan Kinerja Karyawan. Disertasi. PPS-UH, Makassar.

Jahangir, N. (2004). Organizational Citizenship Behavior: Its Nature And Antecedents. BRAC University Journal, vol. I, no. 2, 2004, pp. 75-85

Jusmin, Ahmad, Syahnur Said, Muh Jobhaar Bima, and Roslina Alam. (2016). Specific Determinants of Work Motivation, Competence, Organizational Climate, Job Satisfaction and Individual Performance: A Study among Lecturers. Journal of Business and Management Sciences 4, no. 3 (2016): 53-59.

Kreitner, R., and Kinicki, A. (2008). Organization Behaviour. New York:McGraw-Hill Higher Education.

Kristensen, M, Nielsen JJ, (2004). Satisfaction and Human., Journal of Physiology.

Ley, Tobias, Dietrich Albert and Stefanie Lindstaedt. (2007). Competency Management Using The Competence Performance Approach: Modeling, 
Assessment, Validation, And Use. http:// www.ideagroup.com.

Loveridge, C.E., and Cumming, S.H. (1996). Nursing Management in The New Paradigm, Gaithersburg, MD: An Aspen Publication

Luthans, F. (2002). Organizations Behavior. New York:McGraw Hill International: John E. Biernat.

Malone, Thomas. (2006). Do Some Business Models Perform Better than Others? MIT Sloan School of Management MIT Sloan Working Paper 4615 06 May 2006

Mathis, R., and Jackson, H. (2006). Manajemen Sumber Daya Manusia. Buku I. Penerjemah Sadeli dan Bayu Jakarta: Salemba Empat.

Mc.Clelland, D. C. (1997). Human motivation. Glenview, IL: Scott, Foresman.

Palagia, M., Brasit, N., and Amar, M. (2010). Remunerasi, Motivasi dan Kepuasan Kerja serta Kinerja Karyawan. Jurnal Manajemen, 1-10.

Qamariah, Inneke dan Fadli. (2011). Pengaruh Perencanaan Dan Kompetensi Karyawan Terhadap Kinerja Karyawan Pada PT. Indonesia Asahan Alumunium Kuala Tanjung.Jurnal Ekonomi, 14(2): h:63-73

Renyut, Bernard C. H. Basri Modding. Jobhar Bima. St. Sukmawati. (2017). The effect of organizational commitment, competence on Job satisfaction and employee performance in Maluku Governor's Office. IOSR Journal of Business and Management (IOSR-JBM) e-ISSN: 2278-487X, p-ISSN: 2319-7668. Volume 19, Issue 11. Ver.III (November. 2017), PP 18-29 www.iosrjournals.org

Robbins, S. P., and Judge T. A, M. (2015). Perilaku Organisasi (Organizational Behavior). Penerjemah: Ratna Saraswati and Febriella Sirait. Pearson Education, Inc New Jersey Authirozed Translation Salemba Empat. Jakarta.

Robbins, S. P., and Judge T. A, M. (2015). Perilaku Organisasi (Organizational Behavior).
Penerjemah: Ratna Saraswati and Febriella Sirait. Pearson Education, Inc New Jersey Authirozed Translation Salemba Empat. Jakarta.

Schuler, R., and Jackson, S. (1999). Human Resource Management: Positioning for the 21st century. Minneapolis: West Pub.Co.

Sriwidodo, Untung dan Agus Budhi Haryanto. (2010). Pengaruh Kompetensi, Motivasi, Komunikasi Dan Kesejahteraan Terhadap Kinerja Pegawai Dinas Pendidikan. Jurnal Manajemen Sumber Daya Manusia, 4(1): h:47-57

Suarli, S and Bachtiar (2009). Manajemen Keperawatan dengan Pendekatan Praktik. Erlangga. Jakarta.

Suprapto. (2009). Pengaruh Kompetensi Dan Motivasi Terhadap Kinerja Pegawai Dengan Kepuasan Sebagai Moderating Variabel. Excellent, 1(1): h:1-19

Swanburg, R.C. and Swanburg R.J (1999). Introductory Management and Leadership for Nurses.Jones and Bartlett Publishers. Toronto, Canada.

Werther, W., and Davis, K. (1996). Human Resources and Personal Management. New York: McGraw Hill. Inc.

Wexley, Kenneth N dan Gary A. Yukl. (2011). Perilaku Organisasi Dan Psikolog. Jakarta : Indek

Winanti, M. B. (2011). Pengaruh Kompetensi terhadap Kinerja Karyawan (Survei pada PT. Frisian Flag Indonesia Wiayah Jawa Barat). Majalah Ilmiah UNIKOM Vol. 7 No. 2, 249267.

Yukl, Garry. (2007). Kepemimpinan dalam Organisasi. Edisi Kelima. Jakarta: Indeks

Zaim, Halil. (2013). Analyzing the Effects of Individual Competencies on Performance: A Field Study In Services Industries In Turkey. publication at: https:// www.researchgate.net/ publication/ 292674651 